IRA-International Journal of Applied Sciences ISSN 2455-4499; Vol.04, Issue 01 (2016)

Institute of Research Advances

http://research-advances.org/index.php/IRAJAS

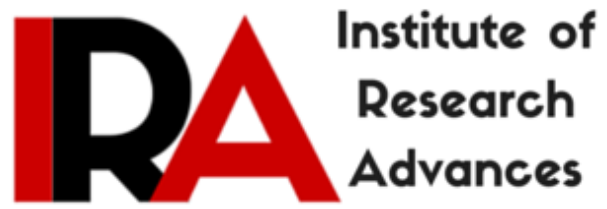

\title{
Phytoremediation of Heavy Metal Industrial contaminated soil by Spiracia oleracea $L$ and Zeamays $L$
}

\author{
Abhilash M.R ${ }^{1}$, Srikantaswamy S ${ }^{1}$, Shiva Kumar $D^{1}$, Jagadish $K^{2}$ and \\ Shruthi $\mathbf{L}^{1}$ \\ ${ }^{1}$ Department of Studies in Environmental Science, University of Mysore, \\ Manasagangothri, Mysuru - 570 006, India. \\ ${ }^{2}$ Centre for Materials Science and Technology, Vijnana Bhavan, University of \\ Mysore, Manasagangotri, Mysuru - 570 006, India.
}

DOI: http://dx.doi.org/10.21013/jas.v4.n1.p22

\section{How to cite this paper:}

M.R, A., S, S., D, S., K, J., \& L, S. (2016). Phytoremediation of Heavy Metal Industrial contaminated soil by Spiracia oleracea L and Zeamays L. IRA-International Journal of Applied Sciences (ISSN 2455-4499), 4(1). doi:http://dx.doi.org/10.21013/jas.v4.n1.p22

(C) Institute of Research Advances

\section{$(\mathrm{cc})$ BY-NC}

This works is licensed under a Creative Commons Attribution-Non Commercial 4.0 International License subject to proper citation to the publication source of the work.

Disclaimer: The scholarly papers as reviewed and published by the Institute of Research Advances (IRA) are the views and opinions of their respective authors and are not the views or opinions of the IRA. The IRA disclaims of any harm or loss caused due to the published content to any party. 


\section{ABSTRACT}

Present days, environment is filled up with a large quantity of toxicants including heavy metals in dissimilar forms. Heavy metal pollution is a significant environmental problem and has its negative impact on human health and agriculture. Several methods already used to clean up the environment from these kinds of contaminants, but most of them are costly and difficult to get optimum results. Currently, phytoremediation is an effective and affordable technological solution used to extract or remove inactive metals and metal pollutants from contaminated soil and water. This technology is environmental friendly and potentially cost effective. This article reports about the mobility, bio-availability and Phytoremediational response of plant in heavy metals in Industrial contaminated soil of Mysuru City, additionally Translocation factor (TF) and Biological Concentration Factor (BCF) also carried to know the ability of the Spiracia oleracea $L$ and Zeamays $L$.

Key words: Heavy Metal, Soil, Mobility, Bio-Availability, Translocation factor (TF) and Biological Concentration Factor (BCF)

\section{INTRODUCTION}

Heavy metals cause major problems to the environment and human health; this problem requires an effective technological solution. Heavy metals are a unique class of toxicants that cannot be broken down into non-toxic forms. Heavy metal-contaminated soils have dramatically increased in recent decades as a result of waste and wastewater discharged from anthropogenic sources (Vakili and Aboutorab, 2003). Using physico-chemical methods such as ion exchange, precipitation, reverse osmosis, evaporation, and chemical reduction can remedy heavy metal contaminated soil; however, these measures require external man-made resources and are expensive. Attention was given to phytoremediation by which plants absorb, transform, and detoxify heavy metals. (Karimi, 2013). In phytoremediation, plants clean up polluted environments. Plants can help clean up many kinds of pollutants that contain metals, pesticides, explosives, and oil. Phytoremediation takes advantage of natural plant processes and requires less equipment and labor than other techniques because plants do most of the work. Moreover, the site can be cleaned up without digging and hauling soil or pumping groundwater, which saves energy (EPA, 2012). Phytoremediation has several aspects: phytoextraction, phytodegradation, rhizofiltration, phytostabilization, and phytovolatilization. Phytoextraction involves hyperaccumulating plants to remove contaminants from the contaminated media and concentrate it in their aboveground plant tissues, which is periodically harvested. If disposing metalenriched plant residue as hazardous material is economically feasible, it can be used for metal recovery (Fayiga, 2005). Phytoremediation technology uses plants to clean contaminated sites and is a promising technology for restoring the environment and ecosystems. The use of spinach for phytoremediation of metalcontaminated soils has been reported in previous studies (Gunduz et al., 2012; Salaskar et al., 2011; Giordani et al., 2005). Spinacia oleracea is an edible flowering plant in the Amaranthaceae family. It is native to central and southwestern Asia. It is an annual plant (rarely biennial) that grows to a height of up to $30 \mathrm{~cm}$. Spinach may survive over winter in temperate regions. The leaves are alternate, simple, and ovate to triangular-based. It is very variable in size from approximately $2 \mathrm{~cm}-30 \mathrm{~cm}$ long and $1 \mathrm{~cm}-15 \mathrm{~cm}$ broad. The plant has larger leaves at its base and small leaves higher on the flowering stem. Zeamays $L$ is belongs to Poaceae, the plant is often $3 \mathrm{~m} \mathrm{(10} \mathrm{ft)} \mathrm{in}$ height though some natural strains can grow $12 \mathrm{~m}$ ( $39 \mathrm{ft})$. The stem is commonly composed of 20 internodes of $18 \mathrm{~cm}$ (7.1 in) length. A leaf, which grows from each node, is generally $9 \mathrm{~cm}(4 \mathrm{in})$ in width and $120 \mathrm{~cm}(4 \mathrm{ft})$ in length. Ears develop above a few of the leaves in the midsection of the plant, between the stem and leaf sheath, elongating by $\sim 3 \mathrm{~mm} /$ day, to a length of $18 \mathrm{~cm}$ (7 in) with $60 \mathrm{~cm}$ (24 in) being the maximum alleged in the subspeciesThis study aims to (1) investigate the potential of Spiracia oleracea $L$ and Zeamays $L$ in phytoremediation of Heavy metal contaminated soil with control in Mysuru City, India 
IRA-International Journal of Applied Sciences

\section{MATERIALS AND METHODS}

The Phytoremidiation studies were carrying out Industrial wastewater contaminated soil. present study attempts was made to know the behavior of heavy metals in Industriall wastewater contaminated soil, Control soil (Collected in normal agricultural land) and Control crops were collected in normal water irrigated area of Mysuru city to find out tangible phytoremidiation standards and identify efficient local wastewater irrigated crop species for phytoremidiation technique and also, calculate the Translocation factor (TF) and Bio-Concentration factor of selected Heavy metals and plant species to assess the actual remediation.

\section{Sampling, Pre-Treatment and Analysis}

The soil and plant samples were collected at different points of the Hebbal Industrial wastewater irrigated zone of Mysuru city, India. The soil and plant samples are collected and dried in sunlight. Soil samples (Root, Stem and Leaves) and plants were dried with the help of oven in the laboratory and then ground in an agate mortar and pestle to pass through a $0.5 \mathrm{~mm}$ stainless steel sieve. Then they were stored in polythene containers at room temperature. The plant samples were analyzed for $\mathrm{pH}$ and digested by using tri acid mixture and $2 \mathrm{ml}$ of aqua-regia has been added to preserve the digested sample and stored in $100 \mathrm{ml}$ distilled container. The digested sample was analyzed for heavy metal concentration by using Inductively Coupled Plasma Atomic Emission Spectroscopy techniques (ICP-AES) by using the PerkinElmer Optima 8000, ICP-OES.

\section{RESULTS AND DISCUSSIONS}

According to the geo-accumulation index of heavy metals (Muller 1969), the soil of the sewage sludge dump site was strongly polluted with $\mathrm{Zn}$; moderately polluted with $\mathrm{Mn}, \mathrm{Cd}, \mathrm{Cr}$, and $\mathrm{Cu}$; and unpolluted to moderately polluted with $\mathrm{Fe}, \mathrm{Pb}, \mathrm{Co}$, and $\mathrm{Ni}$. Generally, the heavy metals in sewage sludges are the result of inputs from human activity such as use of fertilizers; human excreta; domestic water from baths and showers; dishwashing, mine drainage, and run-off water from roofs and roads; and industrial wastewaters discharged into the sewers and processed in sewage treatment plants (Aksoy et al. 2005; Alloway 2013; Mason 2002). Moreover, some heavy metals such as $\mathrm{Fe}$ and $\mathrm{Cu}$ could be added to the sludge through the erosion of water pipes that are made of iron and copper (Bramryd 2013). In addition, the low $\mathrm{pH}$ in the sewage sludge dump site soil often leads to some solubilized soil heavy metals and increases their availability and supply to the plant uptake. Increased availability of heavy metals is reported with decreasing pH in many studies (e.g., Singh and Agrawal 2007; Sukreeyapongse et al. 2002). Regarding the soil of the reference site, this had an alkaline $\mathrm{pH}$ value that is also known to reduce metal availability by enhancing the ability of soil colloids to sorb cations (Sigh et al. 1995). Concentrations of most heavy metals in tissues of nine plant species in the present study were higher in the sewage sludge dump site than in the reference site. This could be due to the low $\mathrm{pH}$ value in the sewage sludge dump soil and its higher soil content of these elements. The results of some research indicated that the land application of sewage sludge increased heavy metals accumulation in plants (Frost and Ketchum 2000; Jamali et al. 2009). Moreover, $\mathrm{pH}$ plays the strongest role in influencing the enrichment processes in the plant rhizosphere (Feng et al. 2011), because a low $\mathrm{pH}$ is optimal for metal availability, where the solubility has been shown to increase with a decreasing $\mathrm{pH}$ (Nanda and Abraham 2013). In the present study, concentrations of most heavy metals were higher in the root than in other plant tissues; this goes in line with many studies reporting that heavy metals are largely retained in below-ground tissues (Bonanno 2013; Eid and Shaltout 2014; Eid et al. 2012a, b). Distribution of metals in different plant tissues depends on their form, water transport, and plant species (Ouzounidou et al. 1995). The variations in heavy metal concentrations in various parts of plants have been ascribed to compartmentalization and translocation through the vascular system (Kim et al. 2003). As stem plays the role of a transferring tissue, minimum 
concentrations of most heavy metals were found in the stem (Planquart et al. 1999). Uptake of heavy Metals by Plant Soluble metals can enter into the root symplast by crossing the plasma membrane of the root endodermal cells, or they can enter the root apoplast through the space between cells. While it is possible for solutes to travel up through the plant by apoplastic flow, the more efficient method of moving up the plant is through the vasculature of the plant, called the xylem. To enter the xylem, solutes must cross the Casparian strip, a waxy coating, which is impermeable to solutes, unless they pass through the cells of the endodermis. Therefore, to enter the xylem, metals must cross a membrane, probably through the action of a membrane pump or channel. Once loaded into the xylem, the flow of the xylem sap will transport the metal to the leaves, where it must be loaded into the cells of the leaf, again crossing a membrane. The cell types where the metals are deposited vary between hyper-accumulator species The lower concentration of $\mathrm{pH}$ of the polluted soil samples shows the indication of mobility of the metal ion. Even in the crushed part of the plant were also analyzed to determine the concentration of accumulated metal from the polluted soil environment. The whole plant body was having low $\mathrm{pH}$, it's a plant inner modification to uptake the minerals and nutrients for the photosynthesis process. All the metal ion in the soil would not be uptake by the plant, but most of the essential ion will be moved to the plant. Even this phenomenon also very useful to transform the metal and remove the metal from polluted soil. These results shows the analyzed plants are good accumulator of heavymetals. By using these plant species up to certain extent toxic heavy metals could be removed from the polluted soil. Lead and Cadmium are the two toxic heavy metal even at the low concentration for the living systems. Zinc, Chromium and Copper are the essential micro nutrients for the proper growth of the plant species. But these micro nutrients should not reach higher concentration, coz it may lead to death of the plants. Hence for the removal or transformation of these toxic heavy metal, phytoremediation technique can be used. The metal concentration, transfer and accumulation of metals from soil to roots, stem and leaf was evaluated through Biological Concentration Factor (BCF). BCF is an index of the ability of the plant to accumulate a particular heavy metal with respect to its concentration in the soil. Translocation Factor (TF) was described as ratio of heavy metals in plant shoot to that in the plant root. The TF value will be higher for those plants which retain the metal in roots without translocation to aerial parts of the plant body. All the examined heavy metal like Copper, Iron, Nickel, Lead and Zinc are shown a superior result in between 40 to 60 respective days time duration with respect to all crops except lead shown below detectable limit in soil.

Table 1: Heavy metal accumulation of Spiracia oleracea $L$ in soil and plant body $(\mathrm{mg} / \mathrm{kg})$ in Industrial wastewater Copper (Cu), Control Soil (1.3)

\begin{tabular}{|l|c|c|c|c|c|c|}
\hline $\begin{array}{l}\text { Plant } \\
\text { Section }\end{array}$ & Control & $\mathbf{2 0}^{\text {th }}$ Day & $\mathbf{3 0}^{\text {th }}$ Day & $\mathbf{4 0}^{\text {th }}$ Day & $\begin{array}{c}\text { Total Bio } \\
\text { Concentration }\end{array}$ & Control \\
\hline Root & 0.07 & 0.1 & 0.1 & 0.1 & 0.284 & 0.14 \\
\hline Leaf & 0.04 & 0.03 & 0.05 & 0.08 & 0.153 & 0.08 \\
\hline
\end{tabular}

Table 2: Heavy metal accumulation of Spiracia oleracea $L$ in soil and plant body $(\mathrm{mg} / \mathrm{kg})$ in Industrial wastewater Iron (Fe) (2317.10), Control Soil (238.20)

\begin{tabular}{|l|c|c|c|c|c|c|}
\hline $\begin{array}{l}\text { Plant } \\
\text { Section }\end{array}$ & Control & $\mathbf{2 0}^{\text {th }}$ Day & $\mathbf{3 0}^{\text {th }}$ Day & $\mathbf{4 0}^{\text {th }}$ Day & $\begin{array}{c}\text { Total Bio } \\
\text { Concentration }\end{array}$ & Control \\
\hline Root & 100.3 & 200.1 & 208.7 & 218.3 & 0.313 & 0.421 \\
\hline Leaf & 15.8 & 63.7 & 68.3 & 70.00 & 0.093 & 0.066 \\
\hline
\end{tabular}


Table 3: Heavy metal accumulation of Spiracia oleracea $L$ in soil and plant body $(\mathrm{mg} / \mathrm{kg})$ in Industrial wastewater Nickel (Ni) (6.6), BDL

\begin{tabular}{|l|c|c|c|c|c|c|}
\hline $\begin{array}{l}\text { Plant } \\
\text { Section }\end{array}$ & Control & $\mathbf{2 0}^{\text {th }}$ Day & $\mathbf{3 0}^{\text {th }}$ Day & $\mathbf{4 0}^{\text {th }}$ Day & $\begin{array}{c}\text { Total Bio } \\
\text { Concentration }\end{array}$ & Control \\
\hline Root & BDL & BDL & BDL & BDL & BDL & BDL \\
\hline Leaf & BDL & BDL & BDL & BDL & BDL & BDL \\
\hline
\end{tabular}

Table 4: Heavy metal accumulation of Spiracia oleracea $L$ in soil and plant body $(\mathrm{mg} / \mathrm{kg})$ in Industrial wastewater Lead (Pb), (BDL), BDL

\begin{tabular}{|l|c|c|c|c|c|c|}
\hline $\begin{array}{l}\text { Plant } \\
\text { Section }\end{array}$ & Control & $\mathbf{2 0}^{\text {th }}$ Day & $\mathbf{3 0}^{\text {th }}$ Day & $\mathbf{4 0}^{\text {th }}$ Day & $\begin{array}{c}\text { Total Bio } \\
\text { Concentration }\end{array}$ & Control \\
\hline Root & 100.3 & 200.1 & 208.7 & 218.3 & 0.313 & 0.421 \\
\hline Leaf & 15.8 & 63.7 & 68.3 & 70 & 0.093 & 0.066 \\
\hline
\end{tabular}

Table 5: Heavy metal accumulation of Spiracia oleracea $L$ in soil and plant body $(\mathrm{mg} / \mathrm{kg})$ in Industrial wastewater Zinc (Zn) (41.8), Control Soil (2.5)

\begin{tabular}{|l|c|c|c|c|c|c|}
\hline $\begin{array}{l}\text { Plant } \\
\text { Section }\end{array}$ & Control & $\mathbf{2 0}^{\text {th }}$ Day & $\mathbf{3 0}^{\text {th }}$ Day & $\mathbf{4 0}^{\text {th }}$ Day & $\begin{array}{c}\text { Total Bio } \\
\text { Concentration }\end{array}$ & Control \\
\hline Root & 1.0 & 6.7 & 7.2 & 8.2 & 0.552 & 0.4 \\
\hline Leaf & BDL & BDL & 0.1 & 0.8 & 0.021 & BDL \\
\hline
\end{tabular}

Table 6: Heavy metal accumulation of Zeamays $L$ Spiracia oleracea $L$ in soil and plant body (mg/kg) in Industrial wastewater Copper (Cu) (3.8), Control Soil (0.5)

\begin{tabular}{|l|c|c|c|c|c|c|}
\hline $\begin{array}{l}\text { Plant } \\
\text { Section }\end{array}$ & Control & $\mathbf{2 0}^{\text {th }}$ Day & $\mathbf{3 0}^{\text {th }}$ Day & $\mathbf{4 0}^{\text {th }}$ Day & $\begin{array}{c}\text { Total Bio } \\
\text { Concentration }\end{array}$ & Control \\
\hline Root & 0.1 & 0.2 & 0.4 & 0.5 & 0.315 & 0.2 \\
\hline Leaf & BDL & BDL & 0.08 & 0.1 & 0.408 & BDL \\
\hline
\end{tabular}

Table 7: Heavy metal accumulation of Zeamays $L$ in soil and plant body $(\mathrm{mg} / \mathrm{kg})$ in Industrial wastewater Iron (Fe) (2.341.8), Control Soil (184.5)

\begin{tabular}{|l|c|c|c|c|c|c|}
\hline $\begin{array}{l}\text { Plant } \\
\text { Section }\end{array}$ & Control & $\mathbf{2 0}^{\text {th }}$ Day & $\mathbf{3 0}^{\text {th }}$ Day & $\mathbf{4 0}^{\text {th }}$ Day & $\begin{array}{c}\text { Total Bio } \\
\text { Concentration }\end{array}$ & Control \\
\hline Root & 60.8 & 197.8 & 209.7 & 210.1 & 0.289 & 0.329 \\
\hline Leaf & 32.4 & 91.7 & 97.5 & 100.5 & 0.137 & 0.175 \\
\hline
\end{tabular}

Table 8: Heavy metal accumulation of Zeamays $L$ in soil and plant body $(\mathrm{mg} / \mathrm{kg})$ in Industrial wastewater Nickel (Ni) (4.7), Control Soil (0.9)

\begin{tabular}{|l|c|c|c|c|c|c|}
\hline $\begin{array}{l}\text { Plant } \\
\text { Section }\end{array}$ & Control & $\mathbf{2 0}^{\text {th }}$ Day & $\mathbf{3 0}^{\text {th }}$ Day & $\mathbf{4 0}^{\text {th }}$ Day & $\begin{array}{c}\text { Total Bio } \\
\text { Concentration }\end{array}$ & Control \\
\hline Root & 0.1 & 0.7 & 0.8 & 0.8 & 0.510 & 0.11 \\
\hline Leaf & 0.4 & BDL & 0.4 & 0.4 & 0.255 & 0.44 \\
\hline
\end{tabular}


Table 9: Heavy metal accumulation of Zeamays $L$ in soil and plant body $(\mathrm{mg} / \mathrm{kg})$ in Industrial wastewater Lead (Pb) (09), BDL

\begin{tabular}{|l|c|c|c|c|c|c|}
\hline $\begin{array}{l}\text { Plant } \\
\text { Section }\end{array}$ & Control & $\mathbf{2 0}^{\text {th }}$ Day & $\mathbf{3 0}^{\text {th }}$ Day & $\mathbf{4 0}^{\text {th }}$ Day & $\begin{array}{c}\text { Total Bio } \\
\text { Concentration }\end{array}$ & Control \\
\hline Root & BDL & BDL & 0.1 & 0.2 & 0.3 & BDL \\
\hline Leaf & BDL & BDL & BDL & BDL & BDL & BDL \\
\hline
\end{tabular}

Table 10: Heavy metal accumulation of Zeamays $L$ in soil and plant body $(\mathrm{mg} / \mathrm{kg})$ in Industrial wastewater Zinc (Zn) (43.6), Control Soil (4.3)

\begin{tabular}{|l|c|c|c|c|c|c|}
\hline $\begin{array}{l}\text { Plant } \\
\text { Section }\end{array}$ & Control & $\mathbf{2 0}^{\text {th }}$ Day & $\mathbf{3 0}^{\text {th }}$ Day & $\mathbf{4 0}^{\text {th }}$ Day & $\begin{array}{c}\text { Total Bio } \\
\text { Concentration }\end{array}$ & Control \\
\hline Root & 1.4 & 8.5 & 9.8 & 13.4 & 0.759 & 0.32 \\
\hline Leaf & 0.5 & 3.1 & 4.2 & 5.5 & 0.305 & 0.11 \\
\hline
\end{tabular}

Table 11: Heavy metal Bio-accumulation in factor in plant body $(\mathrm{mg} / \mathrm{kg})$ in Industrial wastewater by Copper (Overall average)

\begin{tabular}{|c|c|c|c|c|c|c|}
\hline $\begin{array}{c}\text { Heavy } \\
\text { Metal }\end{array}$ & Crops & Root & Stem & Leaf & $\begin{array}{c}\text { Total Bio } \\
\text { Accumulation }\end{array}$ & Control \\
\hline \multirow{4}{*}{ Copper } & Spinach oleracea $\boldsymbol{L}$ & 0284 & 0.207 & 0.153 & 0.046 & 0.26 \\
\cline { 2 - 7 } & Zea mays $\boldsymbol{L}$ & 0.315 & 0.105 & 0.047 & 0.408 & 0.2 \\
\hline \multirow{2}{*}{ Iron } & Spinach oleracea L & 0.313 & 0.172 & 0.093 & 0.580 & 0.783 \\
\cline { 2 - 7 } & Zea mays $\boldsymbol{L}$ & 0.289 & 0.199 & 0.137 & 0.626 & 0.752 \\
\hline \multirow{2}{*}{ Nickel } & Spinach oleracea L & 0.303 & BDL & BDL & 0.303 & BDL \\
\cline { 2 - 7 } & Zea mays $\boldsymbol{L}$ & 0.510 & 0.382 & 0.255 & 1.148 & 0.77 \\
\hline \multirow{2}{*}{ Lead } & Spinach oleracea $\boldsymbol{L}$ & BDL & BDL & BDL & BDL & BDL \\
\cline { 2 - 7 } & Zea mays $\boldsymbol{L}$ & 0.3 & 0.1 & BDL & BDL & BDL \\
\hline \multirow{2}{*}{ Zinc } & Spinach oleracea $\boldsymbol{L}$ & 0.552 & 0.428 & 0.021 & 1.002 & 0.6 \\
\cline { 2 - 7 } & Zea mays $\boldsymbol{L}$ & 0.759 & 0.497 & 0.305 & 1.501 & 0.62 \\
\hline
\end{tabular}

Table 12: Heavy metal Bio-accumulation in factor in plant body $(\mathrm{mg} / \mathrm{kg})$ in Industrial wastewater by Iron (Overall average)

\begin{tabular}{|c|c|c|c|}
\hline Heavy Metal & Crops & $\begin{array}{c}\text { Translocation } \\
\text { Factor }\end{array}$ & Control \\
\hline \multirow{3}{*}{ Copper } & Spinach oleracea $\boldsymbol{L}$ & 1.856 & 1.75 \\
\cline { 2 - 4 } Iron & Zea mays $\boldsymbol{L}$ & 6.702 & 0.1 \\
\hline \multirow{2}{*}{ Nickel } & Spinach oleracea $\boldsymbol{L}$ & 3.365 & 6.348 \\
\cline { 2 - 4 } & Zea mays $\boldsymbol{L}$ & 2.109 & 1.876 \\
\cline { 2 - 4 } & Spinach oleracea $\boldsymbol{L}$ & 0.303 & $\mathrm{BDL}$ \\
\hline \multirow{2}{*}{ Lead } & Zea mays $\boldsymbol{L}$ & 0.2 & 0.25 \\
\hline \multirow{2}{*}{ Zinc } & Spinach oleracea $\boldsymbol{L}$ & $\mathrm{BDL}$ & $\mathrm{BDL}$ \\
\cline { 2 - 4 } & Zea mays $\boldsymbol{L}$ & 0.3 & $\mathrm{BDL}$ \\
\cline { 2 - 4 } & Spinach oleracea $\boldsymbol{L}$ & 2.285 & 1.0 \\
\hline & Zea mays $\boldsymbol{L}$ & 2.488 & 2.5 \\
\hline
\end{tabular}




\section{CONCLUSION}

In this study, it has been found that, Spiracia oleracea $L$ and Zeamays $L$ plant species were more effective in accululating certain metals compared to other species grown at the contol soil. The results indicated that most species grown at the Industrial site are enriched with heavy metals relative to those at the reference site, which suggests that the sludge could not be used as an organic fertilizer particularly for food crops. In the present study, establishing a pattern of translocation of heavy metals from the root to the shoot of plants can be very useful in biological monitoring of heavy metals contamination as well as selection of heavy metals accumulator species. Zeamays $L$ is considered a hyperaccumulator Iron and clearly indicates that they are better able to accumulate heavy metals and are therefore more suitable for phytoremediation purposes.

\section{REFERENCES:}

1. Aksoy A, Demirezen D, Duman F. 2005. Bioaccumulation, detection and analyses of heavy metal pollution in Sultan Marsh and its environment. Water Air Soil Pollut 164:241-255.

2. Alloway BJ. 2013. Heavy metals in soils: trace metals and metalloids in soils and their bioavailability. Dordrecht: Springer.

3. Bonanno G. 2013. Comparative performance of trace element bioaccumulation and biomonitoring in the plant species Typha domingensis, Phragmites australis and Arundo donax. Ecotoxicol Environ Safe 97:124-130

4. Bramryd T. 2013. Long-term effects of sewage sludge application on the heavy metal concentrations in acid pine (Pinus sylvestris L.) forests in a climatic gradient in Sweden. Forest Ecol Manage 289:434-444.

5. Eid EM, El-Sheikh MA, Alatar AA. 2012a. Uptake of Ag, Co and Ni by the organs of Typha domingensis (Pers.) Poir. ex Steud. in Lake Burullus and their potential use as contamination indicators. Open J Modern Hydrol 2:21-27.

6. Eid EM, Shaltout KH, El-Sheikh MA, Asaeda T. 2012b. Seasonal courses of nutrients and heavy metals in water, sediment and above- and belowground Typha domingensis biomass in Lake Burullus (Egypt): perspective for phytoremediation. Flora 207:783-794.

7. EPA (2012). A Citizen's Guide to Phytoremediation. EPA 542-F-12016.

8. Fayiga AO (2005). Phytoremediation of arseniccontaminated soil and groundwater. $\mathrm{PhD}$ Dissertation, University of Florida.

9. Feng J, Wang Y, Zhao J, Zhu L, Bian X, Zhang W. 2011. Source attributions of heavy metals in rice plant along highway in Eastern China. J Environ Sci 23:1158-1164.

10. Frost HL, Ketchum LH. 2000. Trace metal concentration in durum wheat from application of sewage sludge and commercial fertilizer. Adv Environ Res 4:347-355.

11. Giordani C, Cecchi S, Zanchil C (2005). Phytoremediation of Soil Polluted by Nickel Using Agricultural Crops. Environ. Manag., 36(5): 675-681.

12. Gunduz S, Uygur FN, Kahramanoglu I (2012). Heavy metal Phytoremediation potentials of Lepidum sativum L., Lactuca sativa L., Spinacia oleracea L. and Raphanus sativus L. Herald Journal of Agriculture and Food Science Res., 1(1): 001- 005

13. Jamali MK, Kazi TG, Arain MB, Afrid HI, Jalbani N, Kandhro GA, Shah AQ, Baig JA. 2009. Heavy metal accumulation in different varieties of wheat (Triticum aestivum L.) grown in soil amended with domestic sewage sludge. J Hazard Mater 164:1386-1391.

14. Karimi N (2013). Comparative Phytoremediation of Chromium-Contaminated Soils by Alfalfa (Medicago sativa) and Sorghum bicolor (L) Moench. International Journal of Scientific Research in Environmental Sciences, 1(3): 44- 49.

15. Kim IS, Kang HK, Johnson-Green P, Lee EJ. 2003. Investigation of heavy metal accumulation in Polygonum thunbergii for phytoextraction. Environ Pollut 126:235-243.1:161-179

16. Mason CF. 2002. Biology of freshwater pollution. San Francisco (CA): Benjamin Cummings. 
17. Muller G. 1969. Index of geoaccumulation in sediments of the Rhine River. Geol J 2:108-118. Nanda S, Abraham A. 2013. Remediation of heavy metal contaminated soil. Afr J Biotechnol 12:3099-3109

18. Navas A, Bermudez F, Mach in J. (1998). Influence of sewage sludge application on physical and chemical properties of gypsisols. Geoderma 87:123-135.

19. Ouzounidou G, Ciamporova M, Moustakas M, Karataglis S. 1995. Responses of maize (Zea mays L.) plants to copper stress I. Growth, mineral content and ultrastructure of roots. Environ Exp Bot 35:167- 176.

20. Planquart P, Bonin G, Prone A, Massiani C. 1999. Distribution, movement and plant availability of trace metals in soils amended with sewage sludge compost: application to low metal loading. Sci Total Environ 24 .

21. Salaskar D, Shrivastava M, Kale SP (2011). Bioremediation potential of spinach (Spinacia oleracea L.) for decontamination of cadmium in soil. Current Sci., 101(10): 1359-1363.

22. Sigh BR, Narwai RP, Jeng AS, Almas A. 1995. Crop uptake and extractability of cadmium in soils naturally high in metals at different pH levels. Commun Soil Sci Plant Anal 26:2123-2142.

23. Singh RP, Agrawal M. 2007. Effects of sewage sludge amendment on heavy metal accumulation and consequent responses of Beta vulgaris plants. Chemosphere 67:2229-2240.

24. Sukreeyapongse O, Holm PE, Strobel BW, Panichsakpatana S, Magid J, Hansen HCB. 2002. pH dependent release of cadmium, copper, and lead from natural and sludge-amended soils. J Environ Qual 31:1901- 1909.

25. Vakili AH, Aboutorab M (2013). The Potential of Lepidium sativum for Phytoremediation of Contaminated Soil with Cadmium. International Journal Scientific Research in Knowledge, 1(2): 20-24. 